\title{
Frequency of pyrethroid resistance in human head louse treatment: systematic review and meta-analysis
}

\author{
Jalal Mohammadi $^{1}$, Kourosh Azizi ${ }^{1,2}$, Hamzeh Alipour ${ }^{1,2, *}$ (D), Mohsen Kalantari ${ }^{1,2}$, Masoumeh Bagheri ${ }^{1}$, \\ Marzieh Shahriari-Namadi ${ }^{1}$, Saeedeh Ebrahimi, and Mohammad D. Moemenbellah-Fard ${ }^{1,2, *}$ \\ ${ }^{1}$ Department of Biology and Control of Disease Vectors, School of Health, Shiraz University of Medical Sciences, 71645 Shiraz, Iran \\ ${ }^{2}$ Research Center for Health Sciences, Institute of Health, Shiraz University of Medical Sciences, 71645 Shiraz, Iran
}

Received 26 October 2021, Accepted 10 December 2021, Published online 22 December 2021

\begin{abstract}
Head lice (Pediculus humanus capitis) are one of the most common insects causing infestations in humans worldwide, and infestation is associated with adverse socio-economic and public health effects. The development of genetic insensitivity (e.g., target site insensitivity $=$ knockdown resistance or $k d r$ ) to topical insecticides has impaired effective treatment. Therefore, this study was undertaken to review and meta-analyze the frequency of pyrethroid resistance in treated head louse populations from the beginning of 2000 to the end of June 2021 worldwide. In order to accomplish this, all English language articles published over this period were extracted and reviewed. Statistical analyses of data were performed using fixed and random effect model tests in meta-analysis, Cochrane, meta-regression and I2 index. A total of 24 articles from an initial sample size of 5033 were accepted into this systematic review. The mean frequency of pyrethroid resistance was estimated to be $76.9 \%$. In collected resistant lice, $64.4 \%$ were homozygote and $30.3 \%$ were heterozygote resistant. Globally, four countries (Australia, England, Israel, and Turkey) have 100\% $k d r$ gene frequencies, likely resulting in the ineffectiveness of pyrethrin- and pyrethroid-based pediculicides. The highest resistance recorded in these studies was against permethrin. This study shows that pyrethroid resistance is found at relatively high frequencies in many countries. As a result, treatment with current insecticides may not be effective and is likely the cause of increased levels of infestations. It is recommended that resistance status be evaluated prior to insecticide treatment, to increase efficacy.
\end{abstract}

Key words: Allele, Control, Ectoparasite, Kdr genes, Pediculus, Therapy, Pyrethrum.

Résumé - Fréquence de la résistance aux pyréthroïdes dans le traitement du pou de tête chez l'homme : revue systématique et méta-analyse. Les poux de tête (Pediculus humanus capitis) sont l'un des insectes les plus courants à l'origine d'infestations chez l'homme dans le monde, et l'infestation est associée à des effets socio-économiques et de santé publique néfastes. Le développement d'une insensibilité génétique (par exemple, l'insensibilité au site cible $=$ résistance knockdown ou $k d r$ ) aux insecticides topiques a altéré l'efficacité de leur traitement. Par conséquent, cette étude a été entreprise pour examiner et méta-analyser la fréquence de la résistance aux pyréthroïdes dans les populations de poux de tête étudiées du début 2000 à la fin juin 2021 dans le monde. Pour ce faire, tous les articles en anglais publiés au cours de cette période ont été extraits et examinés. Les analyses statistiques des données ont été effectuées à l'aide de tests de modèles à effets fixes et aléatoires dans la métaanalyse, Cochrane, méta-régression et indice I2. Un total de 24 articles provenant d'un échantillon initial de 5033 ont été acceptés dans cette revue systématique. La fréquence moyenne de la résistance aux pyréthroïdes a été estimée à 76,9\%. Chez les poux résistants collectés, 64,4\% étaient homozygotes résistants et 30,3\% étaient hétérozygotes résistants. À l'échelle mondiale, quatre pays (Australie, Angleterre, Israël et Turquie) ont des fréquences de gène $k d r$ de $100 \%$, ce qui entraîne probablement une inefficacité des pédiculicides à base de pyréthrine et de pyréthrinoïde. La résistance la plus élevée enregistrée dans ces études était celle contre la perméthrine. Cette étude montre que la résistance aux pyréthroïdes est trouvée à des fréquences relativement élevées dans de nombreux pays. En conséquence, le traitement avec les insecticides actuels peut ne pas être efficace et est probablement la cause d'une augmentation des niveaux d'infestation. Il est recommandé d'évaluer le statut de résistance avant le traitement insecticide, pour augmenter son efficacité.

*Corresponding authors: alipour_h@gmail.com, alipoorh@sums.ac.ir; momenbf@sums.ac.ir,momenbf@yahoo.com which permits unrestricted use, distribution, and reproduction in any medium, provided the original work is properly cited. 


\section{Introduction}

Infestations of humans by Pediculus lice (Pediculosis) are increasing both in developed and developing countries alike [6]. Humans host three different kinds of lice: head lice (Pediculus humanus capitis De Geer, 1767) (Anoplura: Pediculidae), body lice (Pediculus humanus humanus), and pubic lice (Pthirus pubis). Head lice usually live on the scalp and body lice are commonly found in the folds of clothing of infested people. Both feed exclusively on human blood.

The prevalence of head lice varies in different parts of the world, but it is higher in school children, adolescents and girls than in other groups $[1,44,66]$. Sporadic reports on the prevalence of head lice in school children show variable levels of pediculosis with the European Union reporting a 2.1\% infestation rate [5], Greece 5.3\% [60], Poland 16.3\% [64], Ethiopia $65.7 \%$ [15], Syria 14.3\% [35], and Iran 7.4-10.5\% [52, 54]. The global prevalence rate of head louse infestation is about $19 \%$, as reported in a recent meta-analysis-based systematic review [32]. These data reflect the scope and variability of this problem.

Treatment and control of pediculosis is of particular importance due to its widespread occurrence. Treatment is commonly performed using topical insecticides, including permethrin $1 \%$, malathion $0.5 \%$, lindane $1 \%$, and oral ivermectin [67]. Initially, permethrin and lindane successfully treated $89.7 \%$ and $95 \%$ of cases of head lice infestations, respectively $[36,50]$. Lindane is now widely banned due to neurological reasons and there are increasing levels of resistance to insecticides such as pyrethroids due to their extensive use in treating pediculosis [24, 34]. In recent decades, the efficacy of the most widely used pyrethroid, permethrin, for the treatment of pediculosis has decreased to an unacceptably low level in the United Kingdom [23].

Pyrethroids, such as permethrin, bind to voltage-sensitive sodium channels (VSSC) in the nervous system and cause prolonged opening of these channels. Rapid and uncontrolled sodium influx leads to nerve depolarization which eventually causes muscle paralysis and death $[26,29]$. A common mechanism of insecticide resistance is target site insensitivity, such as knockdown resistance $(k d r)$, where point mutations in the target site (VSSC) reduce the binding of insecticides (i.e., dichlorodiphenyl trichloro-ethane or DDT and permethrin), causing nerve insensitivity and resistance. Resistance to pyrethroids (and DDT) was first described in flying insects, such as houseflies Musca domestica, causing a sudden, sometimes reversible, "death like effect" and so-called knockdown resistance [58, 69].

This resistance is a heritable genetic trait caused by recessive allele mutations, which occur in a wide range of insects that have been exposed to either DDT or a pyrethroid, or both, at some point in their evolutionary history. $K d r$-causing point mutations (e.g., M815I, T917I, and L920F) in the VSSC $\alpha$-subunit gene have been identified in resistant lice and are used as markers of pyrethroid resistance $[13,25,26]$. Although the sole detection of $k d r$ gene mutations may not directly predict clinical failure, their rising frequency in head louse populations coincides with publications on product failures in controlled studies [72].

In general, resistance to insecticides has led to failure to treat or incompletely treat pediculosis, increasing its varied prevalence and intensity worldwide during the last three decades. As a result, it is necessary to use alternative insecticides or other treatment approaches. Preliminary knowledge of the frequency of genetic resistance in human head lice to topical insecticides is of particular importance in order to determine the use of appropriate treatment protocols [19, 24]. Therefore, the present study aimed to investigate the frequency of pyrethroid resistance to pediculicides via a systematic review and meta-analysis.

\section{Methods}

A systematic review and meta-analysis were conducted to investigate pyrethroid resistance in head lice and its treatment. The Preferred Reporting Items for Systematic Reviews and Meta-Analyses (PRISMA) standard guideline was used to follow up the review process and report findings [45].

\section{Search strategy and selection criteria}

This review focused on studies about $k d r$ gene mutations and treatment of head lice that were published in English language journals between the year 2000 and June 2021. The Scopus, Web of Science, PubMed (including Medline), Cochrane database library and Science Direct databases were searched in medical subject headings $(\mathrm{MeSH})$ and relevant keywords: Resistance, Knockdown Resistance, Insecticide Resistance, Pyrethroid Resistance, Pediculicide Resistance, Genetic Diversity, Molecular Monitoring, Resistance Mutations, Head Lice, Head Louse, Pediculosis, and Treatment. They were used in isolation or combination through the Boolean method.

\section{Inclusion and exclusion criteria}

All English-language articles published worldwide on $k d r$ gene mutations and human head lice treatment, which were of high quality, were entered into the study. Articles of low quality as outlined in the next paragraph, studies conducted on insects other than lice, uncertainty of mutation, and no reporting of resistance frequency were excluded from the study. Additionally, review studies, meta-analyses, case reports or series of cases were excluded.

\section{Quality assessment}

The quality of the articles was assessed using the Strobe checklist (Strengthening the Reporting of Observational Studies in Epidemiology) [68]. This checklist has 22 parts that were scored based on the importance of each section, the lowest score of this checklist was 15 and the maximum was 33. In this study, an acceptable score of 20 was considered [16].

\section{Screening and data extraction}

The search results were imported into Endnote software v.x8-1 and duplicate titles were deleted. Selected studies were entered into abstract reading and were checked against the inclusion criteria. Of these, the relevant studies were selected 


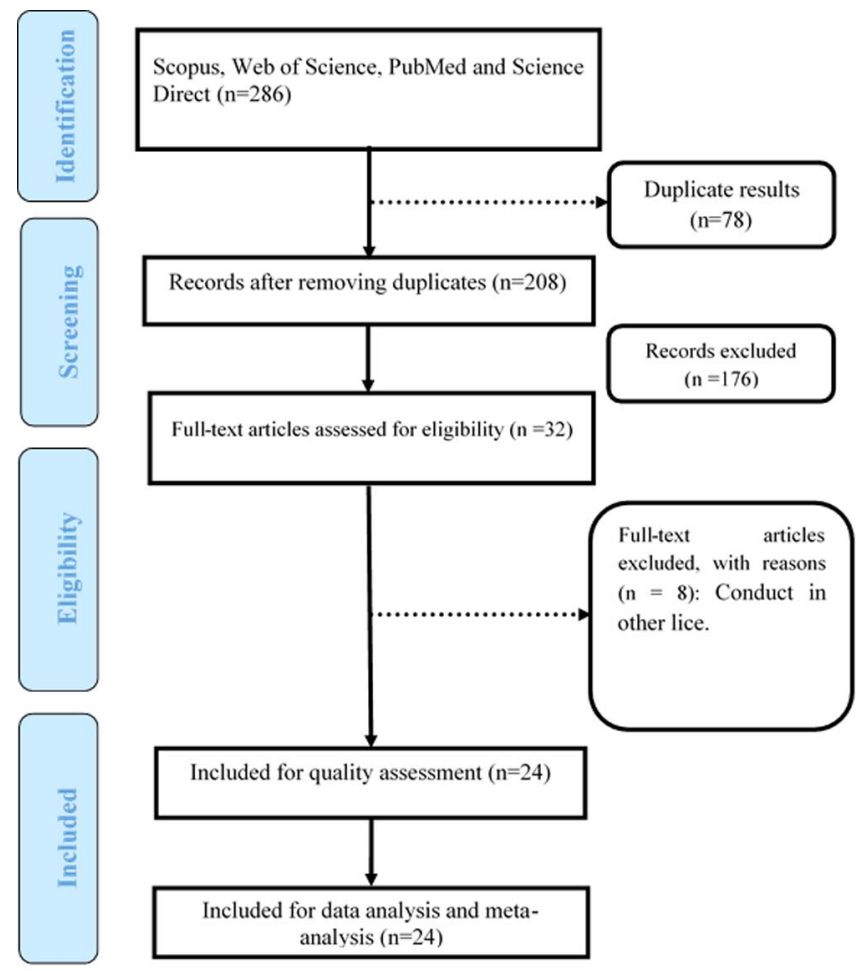

Figure 1. The PRISMA flow chart diagram.

for independent full-text reading by two researchers and a third person as the expert-epidemiologist checked the results. Reasons for the rejection of studies were mentioned and in case of disagreement between the researchers, the perspective of a third researcher was sought. A checklist was used to extract data from the selected studies in terms of the sample size, study location, study period, type of study, pyrethroid resistance, type of mutation of $k d r$ genes, and type of treatment.

\section{Selection of articles}

By searching databases, 286 studies were extracted. Initially, the articles were entered into Endnote software and after an initial review, 78 articles were removed from the study due to duplication. Then, by reviewing the titles and abstracts of articles, 176 articles were removed due to irrelevance and after reviewing the full text of articles, 8 articles were excluded due to investigation of other lice species. Finally, 24 articles met the inclusion and eligibility criteria and entered the process of systematic review (Fig. 1).

\section{Results}

A total of 24 articles from an initial sample size of 5033 that were conducted between 2000 and 2021 were included in this study. The characteristics of the surveyed studies are presented in Table 1. Based on these findings, the globally reported mean frequency of pyrethroid resistance was estimated to be $76.9 \%$ (95\%, CI: 68.7-85). In collected lice populations with $k d r$ mutations, $64.4 \%$ were homozygote resistant and $30.3 \%$ heterozygote resistant (Figs. 2-4). The publication bias was investigated using a funnel plot, and due to the symmetry of the diagram, it can be assumed that diffusion bias did not occur, and the Egger test also confirmed it $(p=0.032)$ (Fig. 5). The relationship between study year and resistance status revealed that with increasing study year the frequency of resistance also increased (Fig. 6).

From studies conducted in 21 countries as outlined in 24 screened articles, the head louse sample populations collected from four countries (Australia, England, Israel, and Turkey) have complete (100\%) $k d r$ allele frequencies, suggesting that pyrethrin- and pyrethroid-based pediculicides are ineffective in these areas. The rest of them (17) reported frequencies ranging from zero to $99.3 \%$, pointing to incomplete allele phenotypes. The largest (670) and the lowest (20) head lice sample sizes were attributed to studies conducted by French and American researchers, respectively.

A total of $40 k d r$ allele mutations were discovered in these screened articles, of which the first (30\%) and the second $(20 \%)$ most frequently identified allele phenotypes were T917I and T932I (amino acid Threonine replaced by Isoleucine at loci number: 917 and 932), respectively. So, half $(50 \%)$ of all reported mutations have so far been attributed to TI conversion.

\section{Discussion}

Based on the present findings, more than $70 \%$ of sampled human head lice were resistant to pyrethroid insecticides, and this rate has been increasing in recent decades, possibly following enhanced surveillance for pediculosis from head lice. Consequently, it is recommended that one should first determine the $k d r$ allele frequencies in local human head louse populations, outline its zygote status and gene mutation type, design effective treatment methods, and then treat patients.

One possible reason for the detection of different levels of pyrethroid resistance in different parts of the world is the fact that different methods were used to diagnose genetic resistance in local head louse populations. Another factor could be the discrepancies between head louse lineages (see clades below) over different continents. Most probably, frequent application of various organochlorine and/or pyrethroid insecticides, and hence the resulting selection pressure against head lice could have given rise to the different levels of $k d r$ allele frequencies in different regions allowing only heterozygote first to survive and reproduce. Different populations in terms of age and gender over disparate seasons could also be involved.

As mentioned above, pyrethroid target receptor mutation is a heritable recessive trait caused by persistent exposure to the above-named insecticides. Most often, refractoriness to pyrethrin- and pyrethroid-based pediculicides (and less to the organochlorine DDT) is caused by $k d r$-type mutations in the VSSC $\alpha$ - subunit gene of head lice. The head louse sample populations collected from five countries (Turkey, Australia, England, Israel, and Uruguay) were found to have complete (100\%) $k d r$ allele frequencies, suggesting that pyrethrin- and pyrethroid-based pediculicides are ineffective and their applications should be stopped in these areas [33]. 
Table 1. General characteristics of the included studied in the data analysis process.

\begin{tabular}{|c|c|c|c|c|c|}
\hline Authors & Year of study & Place of study & Sample size & $K d r$ allele mutation & Proportion $k d r(\%)$ \\
\hline$[30]$ & 2021 & Iran & 54 & K794E, F815I, and N818D & 51 \\
\hline [41] & 2020 & Honduras & 83 & T917I & 93.9 \\
\hline \multirow[t]{3}{*}{ [37] } & 2020 & Turkey & 150 & T917I & 100 \\
\hline & & & & L920F & 99.3 \\
\hline & & & & M815I & 100 \\
\hline [8] & 2020 & Thailand & 260 & T917I & 40 \\
\hline [59] & 2019 & Chile & 99 & T917I & 94.9 \\
\hline [22] & 2019 & Madagascar & 159 & T917I & 70 \\
\hline [57] & 2019 & Mexico & 468 & T929I & 78.2 \\
\hline [21] & 2017 & Georgia & 259 & T917I & 64.86 \\
\hline [29] & 2016 & United States & 141 & M815I, T917I, and L920F & 98.4 \\
\hline [72] & 2014 & United States & 291 & T917I & 90.7 \\
\hline$[62]$ & 2014 & Argentina & 154 & M815I, T917I, and L920F & 91.6 \\
\hline [18] & 2014 & France & 167 & M815I, T917I, and L920F & 64.1 \\
\hline [46] & 2012 & Israel & 192 & M815I, T929I and I932F & 93 \\
\hline [7] & 2012 & France & 670 & T917I and L920F & 98.7 \\
\hline \multirow[t]{12}{*}{ [13] } & 2010 & North America & 20 & M815I, T917I and L920F & 85.25 \\
\hline & & Argentina & & & 93 \\
\hline & & Brazil & & & 75 \\
\hline & & England & & & 100 \\
\hline & & Denmark & & & 92 \\
\hline & & Czech Republic & & & 33 \\
\hline & & Egypt & & & 15 \\
\hline & & Israel & & & 100 \\
\hline & & South Korea & & & 0 \\
\hline & & Thailand & & & 0 \\
\hline & & New Guinea & & & 0 \\
\hline & & Australia & & & 100 \\
\hline [38] & 2009 & Japan & 630 & M815I, T929I, and L932F & 8.7 \\
\hline [14] & 2008 & Argentina & 120 & - & - \\
\hline [20] & 2007 & France & 112 & T929I & 77.8 \\
\hline [61] & 2006 & England & 316 & T917I & 82.6 \\
\hline [40] & 2006 & Denmark & 208 & T929I and L932F & - \\
\hline [70] & 2003 & United States & 33 & T929I and L932F & 15 \\
\hline \multirow[t]{2}{*}{ [28] } & 2003 & United States & 74 & T929I and L932F & 78 \\
\hline & & & 29 & & 97 \\
\hline [71] & 2004 & United States & 121 & T929I and L932F & - \\
\hline [43] & 2000 & England & 223 & T929I and L932F & - \\
\hline
\end{tabular}

The findings of this meta-analysis on $k d r$ gene frequencies revealed that about $33 \%$ of human head lice were sensitive to the currently used insecticides, such as permethrin, in different parts of the world. However, most of them $(\approx 67 \%)$ were resistant to the treatments. From our analysis, it is evident that most $(81 \%)$ countries in the review were still in the incomplete phase for the selection of $k d r$ allele mutations. This finding indicates an increasing risk associated with the extensive and mismanaged use of over-the-counter (OTC) pediculicides, such as permethrin, in mostly developed parts of the world. TI amino acid conversion constituted $50 \%$ of the identified phenotypes, which may substantiate the higher genetic plasticity of pyrethroid resistance due to this phenotypic mutation with respect to other types of mutations recorded so far.

To serve as an example of the variable sensitivity of head louse populations to different pediculicides, 10 years of research in North America revealed that the frequency of pyrethroid resistance between 1999 and 2009 was about 84.4\%. However, this frequency was reported to be $97.1 \%$ in 2008 and $99.6 \%$ between 2007 and 2009. This finding demonstrates that the frequency of resistance increased in those years in this region [72]. These authors had earlier observed permethrin resistance in human head lice in California and Florida, USA but they were susceptible to the long-prohibited organochlorine lindane [71]. In susceptible populations of head louse, these recessive resistance alleles seem to be scarce. It is thus postulated that increased frequency of diagnosis and treatment would cause stronger selection pressure for pediculicide insensitivity, paving the way for heterozygotes to spread first, while reversion of head louse target receptor coding genes to susceptible allele status against a specific pediculicide formulation could emanate from its lack of application during the evolutionary history.

Various techniques have been used to diagnose genetic resistance. Polymerase chain reaction (PCR) was used to screen for mutations in T917I, L920F, M815I alleles, and detect $k d r$ mutation in selected head louse populations in Turkey [37]. This method required small amounts of DNA for analysis, 


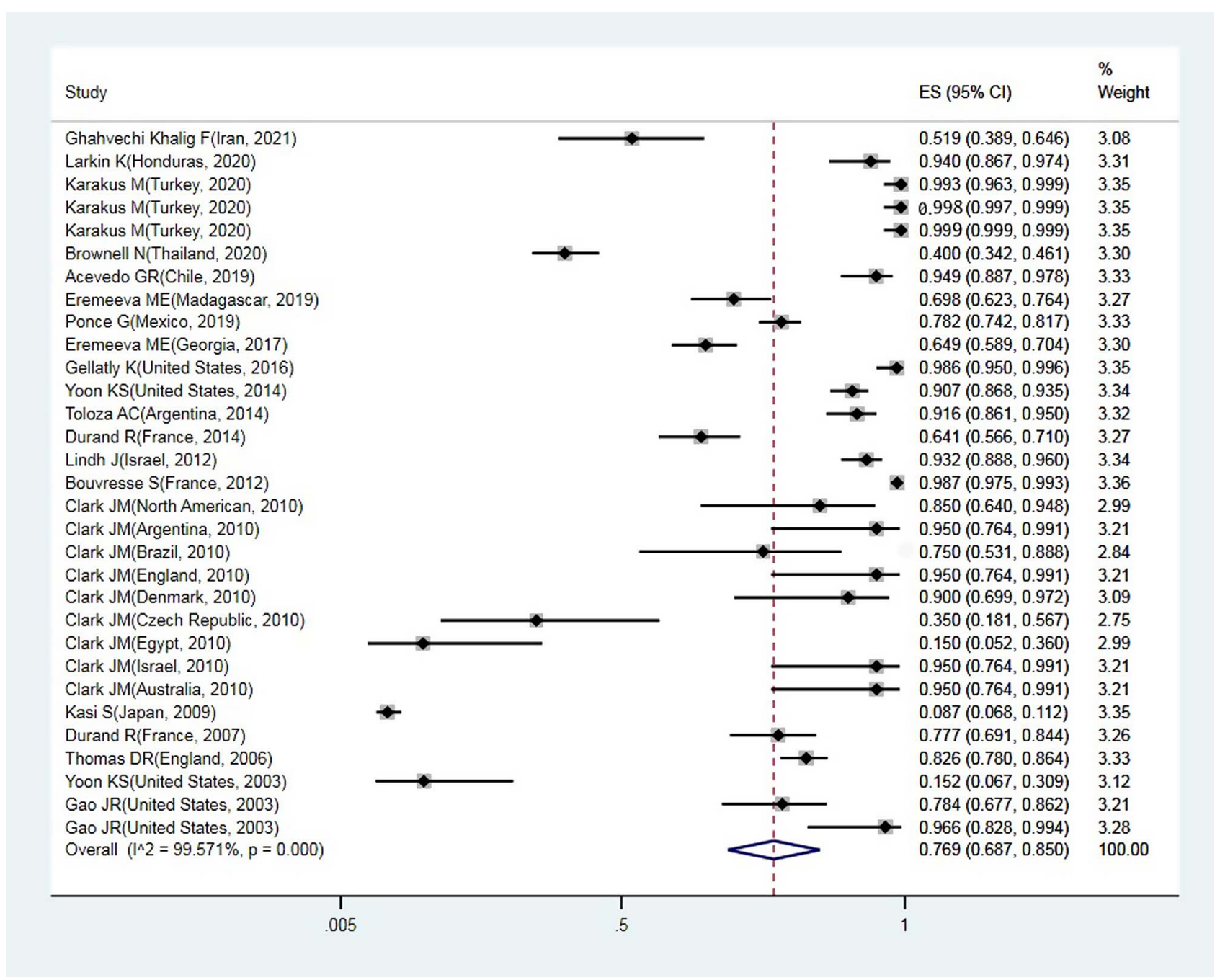

Figure 2. Forest plots of the proportion of resistance in lice and $95 \%$ confidence interval based on a random effect model in meta-analysis.

which could be extracted from lice, it could be carried out in a simple laboratory environment, and was suitable for $k d r$ allele mutation screening [21, 26]. Quantitative sequencing (QS) for screening mutations causing the T917I, M815I and L932F amino acid conversions has also been implemented in head lice. Due to its speed, accuracy and simplicity, this method was a good candidate for screening resistant lice on a large scale $[13,42]$. However, studies have shown that this method was mostly used to monitor and survey the levels of high frequencies of genetic mutations in lice populations [12, 29]. Real-time PCR (rtPASA) is another method used to monitor mutations based on frequency change, which has been used for low frequency [13]. Use of the serial invasive signal amplification reaction (SISAR) protocol to screen and diagnose $k d r$ mutations was another development in this field [39]. This method was applied to identify single nucleotide polymorphisms and was an effective method for detecting heterozygous genetic mutations and Hardy-Weinberg equilibrium in lice [29, 47]. The use of this method for $k d r$ alleles screening was also recommended in the United States and Canada [12].
In general, based on the findings of the present study and other studies, screening to diagnose pyrethroid resistance using simple, inexpensive and rapid laboratory methods is essential in order to select an appropriate treatment for the control of pediculosis.

Pediculosis caused by head lice is a major public health concern due to increased frequency and operations to contain these parasites pose even higher risks to human populations than the infestation itself [56]. A range of intervention methods are available for the control of head lice. The mainstay of therapy has overtly been the use of insecticides [52]. Treatment with pyrethroid insecticides resulted in a high degree of resistance, even though insensitivities to lindane had also been reported. As a result, it is necessary to use effective drugs with different active ingredients to treat the infestation. Some researchers have resorted to the use of "green" formulations $[11,51]$ including the oil of the eucalyptus plant species [63], lavender plus peppermint [4], tea tree oil [17], and extracts of citrus for the treatment of pediculosis [27]. Others have recommended the use of physically active dimeticones to treat head 


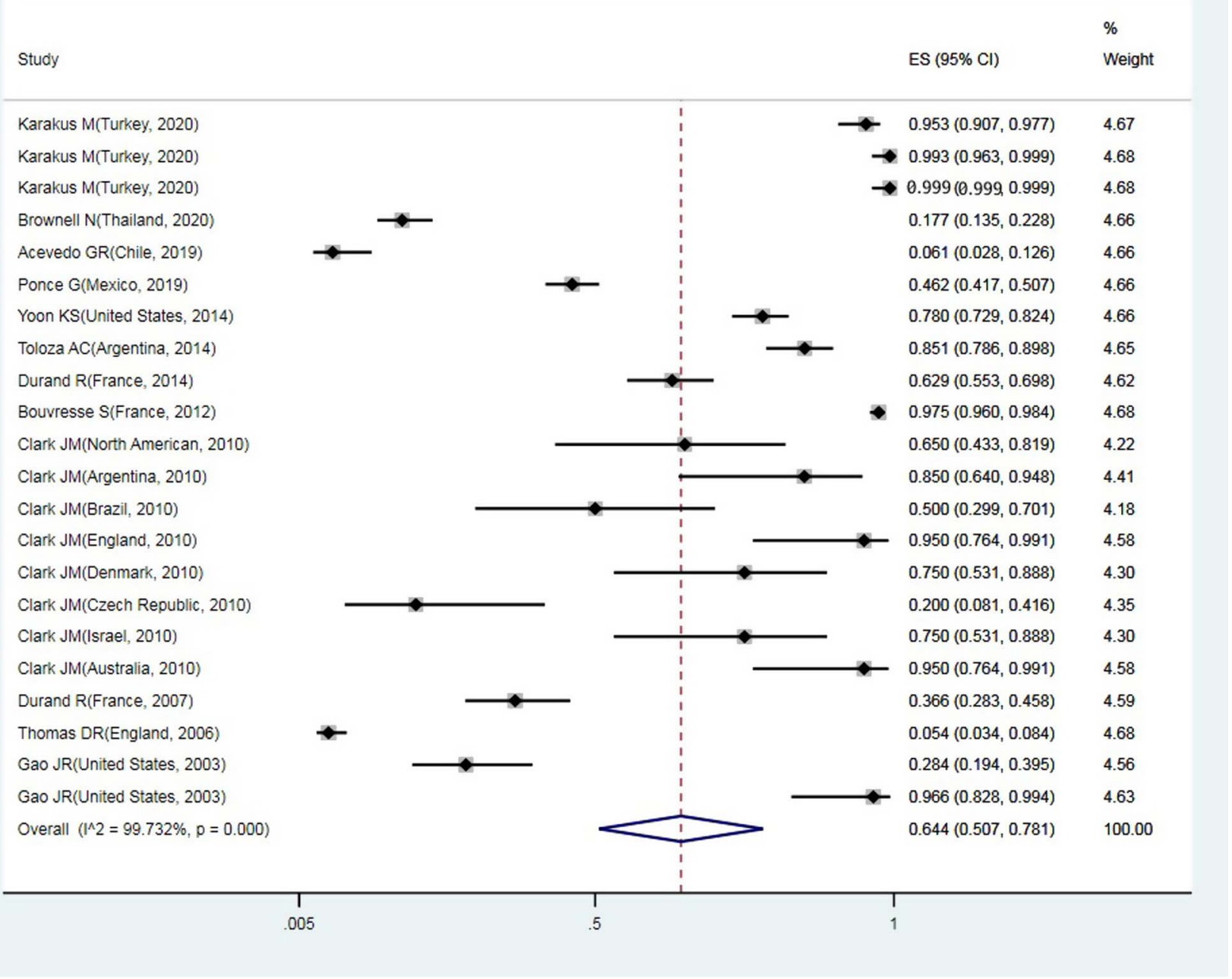

Figure 3. Forest plots of the proportion of homozygote resistant and $95 \%$ confidence interval based on a random effect model in metaanalysis.

lice infestation [19]. Dimeticone lotion causes suffocation and should be applied to the scalp twice for $8 \mathrm{~h}$, but its gel needed only $15 \mathrm{~min}$ to eliminate head lice [9]. Other recommended treatments for pediculosis included Crotamiton $10 \%$, oral ivermectin, benzyl alcohol 5\%, and Spinosad 0.9\% [48, 49]. Isopropyl myristate dissolves the surface wax of lice, which leads to dehydration and death of lice [10]. Desiccation can be performed using heat-generating devices such as Louse Buster, which leads to water loss and death followed by manual removal using a comb $[31,53,55]$.

Lice species are subdivided into clade haplotypes in terms of genome and geographical location. High and rapid diversification into different phylogenetic clades indicates the association between humanoids and head lice dating back to millions of years ago [3]. Head lice have thus globally been differentiated into six clades based on their mitochondrial DNA data. These haplotypes are named into clades A-F. These are grouped according to their territorial propagation. There is, therefore, an essential need to monitor these mutations through geographically specific genetic biomarkers [26] because of increasing failures to first-line treatment since allele mutations related to pyrethroid resistance differ between regions. There is clade A worldwide, clade B mainly in the United States, Europe and Australia, clade C in Africa and Asia, clade D in sub-Saharan Africa, clade $\mathrm{E}$ in West Africa, and clade $\mathrm{F}$ in Argentina and Mexico [2]. Among the above clades, clade $\mathrm{C}$ has more genetic diversity [6, 65]. International travel has caused the spread of clades to other regions and genetic interaction between them, especially clades $A$ and $C$ [26, 65]. It is speculated that genetic exchange between them is rapidly carried out due to the short life cycle of lice and the constant proximity of different types of clades. High and effective genetic exchange and diversity can lead to the spread of resistance genes, but on the contrary also to the maintenance of a reservoir of susceptibility. There is no available data on this topic regarding the dynamics of resistance.

In general, according to the findings of the present study, resistance to permethrin has increased worldwide due to $k d r$ allelic mutations selected by the frequent use of topical pyrethroid and permethrin formulations. Accordingly, it is necessary to use alternative strategies and effective treatment approaches. 


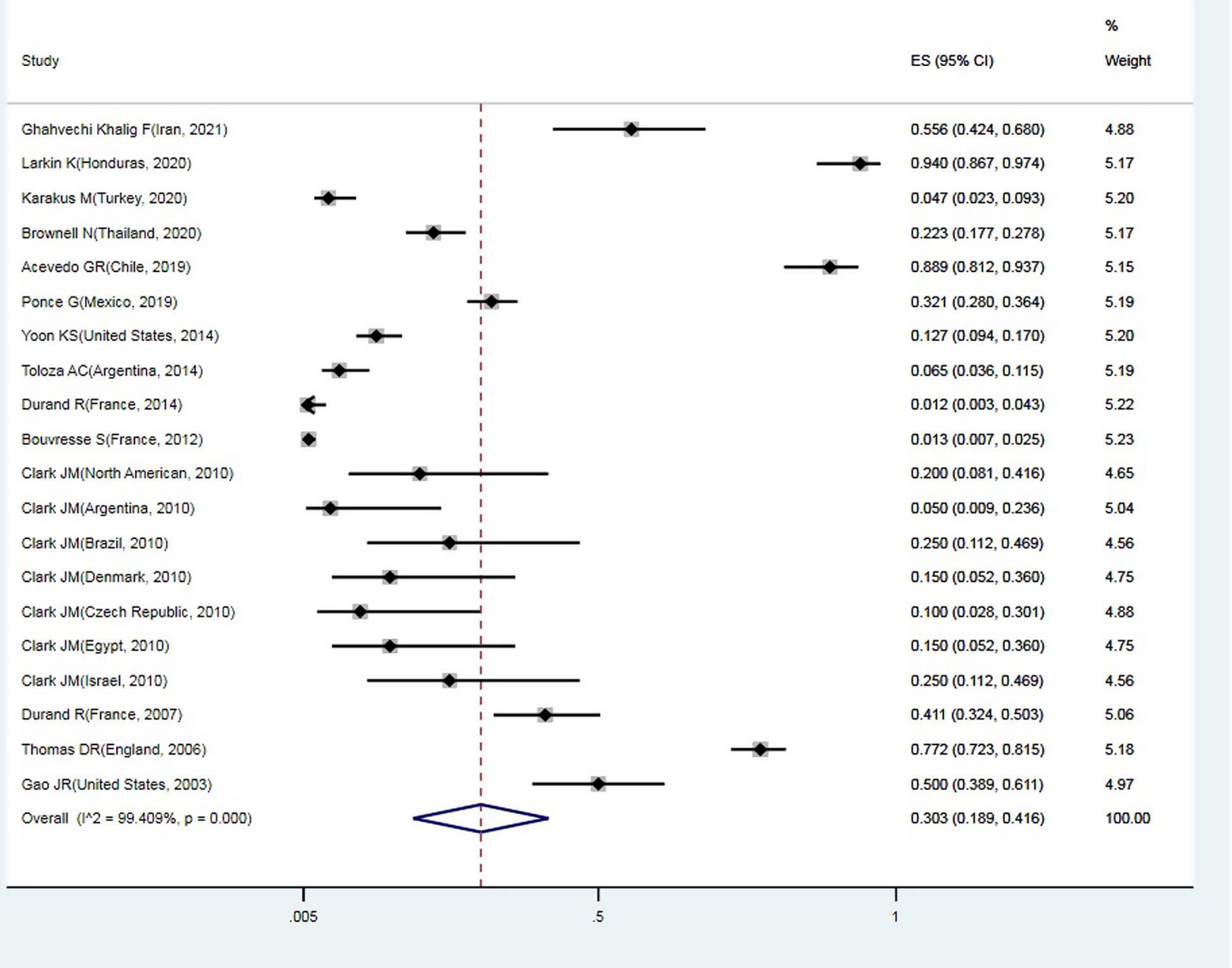

Figure 4. Forest plots of the proportion of heterozygote resistance and 95\% confidence interval based on a random effect model in metaanalysis.

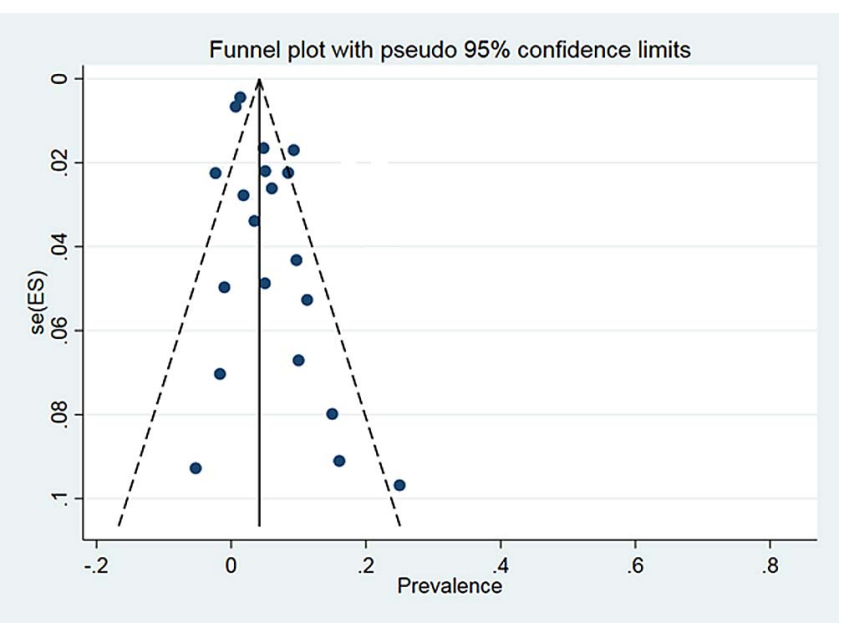

Figure 5. Funnel chart of proportion resistance in the selected studies.

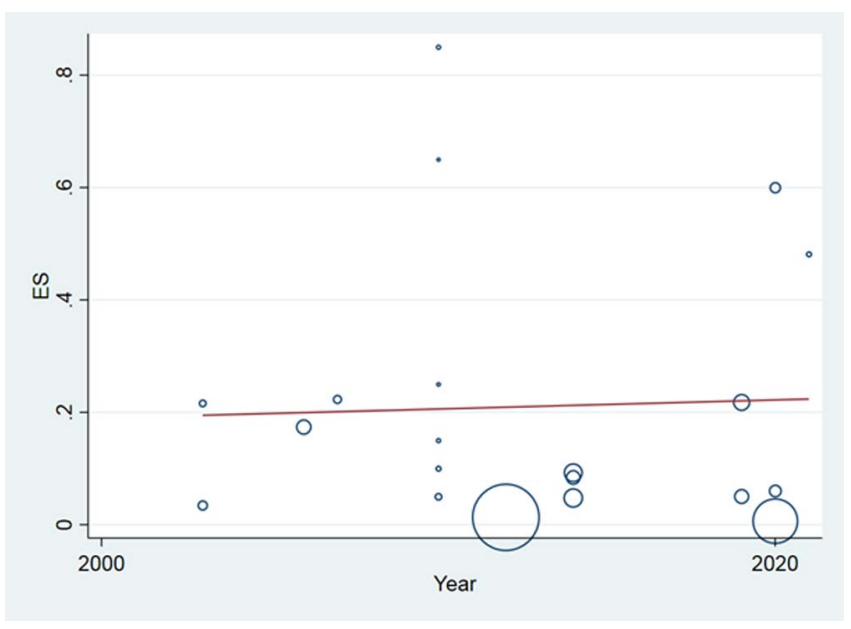

Figure 6. Meta regression chart of the proportion of resistance on the study year. 


\section{Limitations}

Limitations of this study included confinement to English language-based papers. No papers investigated the prevalence of all type $k d r$ resistant alleles. Studies were in different years and different countries in which therapeutic approaches may have differed. There was also much heterogeneity between these studies.

\section{Conclusions}

For the first time, this systematic review and meta-analysis attempted to examine, and found a relatively high frequency of pyrethroid resistance among human head louse populations in different countries. It could be concluded that there has been no study on the dynamics of resistance in human head lice so far. As a result, treatment with current pyrethroids and pyrethrins may not be efficacious in many cases. Based on this, it is recommended that drug resistance be evaluated first and then treatment be initiated with appropriate and effective protocols.

\section{Conflict of interests}

None is declared by the authors who have no competing financial interests or personal relationships that could have appeared to influence this review paper.

Acknowledgements. Our appreciation goes to the staff at Shiraz School of Health. This review was undertaken under the auspices of Shiraz University of Medical Sciences (SUMS) to whom we are indebted.

\section{References}

1. Al-Shahrani SA, Alajmi RA, Ayaad TH, Al-Shahrani MA, Shaurub E-SH. 2017. Genetic diversity of the human head lice, Pediculus humanus capitis, among primary school girls in Saudi Arabia, with reference to their prevalence. Parasitology Research, 116(10), 2637-2643.

2. Amanzougaghene N, Fenollar F, Raoult D, Mediannikov O. 2020. Where are we with human lice? A review of the current state of knowledge. Frontiers in Cellular and Infection Microbiology, 9, 474.

3. Ashfaq M, Prosser S, Nasir S, Masood M, Ratnasingham S, Hebert PD. 2015. High diversity and rapid diversification in the head louse, Pediculus humanus (Pediculidae: Phthiraptera). Scientific Reports, 5(1), 1-13.

4. Audino PG, Vassena C, Zerba E, Picollo M. 2007. Effectiveness of lotions based on essential oils from aromatic plants against permethrin resistant Pediculus humanus capitis. Archives of Dermatological Research, 299(8), 389-392.

5. Bartosik K, Buczek A, Zajac Z, Kulisz J. 2015. Head pediculosis in schoolchildren in the eastern region of the European Union. Annals of Agricultural and Environmental Medicine, 22(4), 599-603.

6. Boutellis A, Abi-Rached L, Raoult D. 2014. The origin and distribution of human lice in the world. Infection, Genetics and Evolution, 23, 209-217.

7. Bouvresse S, Berdjane Z, Durand R, Bouscaillou J, Izri A, Chosidow O. 2012. Permethrin and malathion resistance in head lice: results of ex vivo and molecular assays. Journal of the American Academy of Dermatology, 67(6), 1143-1150.

8. Brownell N, Sunantaraporn S, Phadungsaksawasdi K, Seatamanoch N, Kongdachalert S, Phumee A, Siriyasatien P. 2020. Presence of the knockdown resistance (kdr) mutations in the head lice (Pediculus humanus capitis) collected from primary school children of Thailand. PLoS Neglected Tropical Diseases, 14(12), e0008955.

9. Burgess IF, Brunton ER, Burgess NA. 2013. Single application of $4 \%$ dimeticone liquid gel versus two applications of $1 \%$ permethrin creme rinse for treatment of head louse infestation: a randomised controlled trial. BMC Dermatology, 13(1), 1-7.

10. Burgess IF, Lee PN, Brown CM. 2008. Randomised, controlled, parallel group clinical trials to evaluate the efficacy of isopropyl myristate/cyclomethicone solution against head lice. Pharmaceutical Journal, 280, 371-375.

11. Candy K, Akhoundi M, Andriantsoanirina V, Durand R, Bruel C, Izri A. 2020. Essential oils as a potential treatment option for pediculosis. Planta Medica, 86(09), 619-630.

12. Clark JM. 2009. Determination, mechanism and monitoring of knockdown resistance in permethrin-resistant human head lice, Pediculus humanus capitis. Journal of Asia-Pacific Entomology, 12(1), 1-7.

13. Clark JM. 2010. Permethrin resistance due to knockdown gene mutations is prevalent in human head louse populations. Open Dermatology Journal, 4(1), 63-68.

14. Cueto GM, Zerba EN, Picollo MI. 2008. Evidence of pyrethroid resistance in eggs of Pediculus humanus capitis (Phthiraptera: Pediculidae) from Argentina. Journal of Medical Entomology, 45(4), 693-697.

15. Dagne H, Biya AA, Tirfie A, Yallew WW, Dagnew B. 2019. Prevalence of pediculosis capitis and associated factors among schoolchildren in Woreta town, northwest Ethiopia. BMC Research Notes, 12(1), 1-6.

16. Daliri S, Karimi A, Sayehmiri K, Bazyar J, Sayehmiri F. 2016. Relationship between some maternal and neonatal factors during previous pregnancies and low birth weight in Iran: A systematic review and meta-analysis. Iranian Journal of Obstetrics, Gynecology and Infertility, 19(31), 23-32.

17. Di Campli E, Di Bartolomeo S, Pizzi PD, Di Giulio M, Grande R, Nostro A, Cellini L. 2012. Activity of tea tree oil and nerolidol alone or in combination against Pediculus capitis (head lice) and its eggs. Parasitology Research, 111(5), 1985-1992.

18. Durand R, Bouvresse S, Andriantsoanirina V, Berdjane Z, Chosidow O, Izri A. 2014. High frequency of mutations associated with head lice pyrethroid resistance in schoolchildren from Bobigny, France. Journal of Medical Entomology, 48(1), 73-75.

19. Durand R, Bouvresse S, Berdjane Z, Izri A, Chosidow O, Clark J. 2012. Insecticide resistance in head lice: clinical, parasitological and genetic aspects. Clinical Microbiology and Infection, 18(4), 338-344.

20. Durand R, Millard B, Bouges-Michel C, Bruel C, Bouvresse S, Izri A. 2007. Detection of pyrethroid resistance gene in head lice in schoolchildren from Bobigny, France. Journal of Medical Entomology, 44(5), 796-798.

21. Eremeeva ME, Capps D, Winful EB, Warang SS, Braswell SE, Tokarevich NK, Bonilla DL, Durden LA. 2017. Molecular markers of pesticide resistance and pathogens in human head lice (Phthiraptera: Pediculidae) from rural Georgia, USA. Journal of Medical Entomology, 54(4), 1067-1072.

22. Eremeeva ME, Warang SS, Anderson ML, Capps D, Zohdy S, Durden LA. 2019. Molecular survey for pathogens and markers of permethrin resistance in human head lice (Phthiraptera: Pediculidae) from Madagascar. Journal of Parasitology, 105(3), 459-468. 
23. Feldmeier H. 2012. Pediculosis capitis: new insights into epidemiology, diagnosis and treatment. European Journal of Clinical Microbiology \& Infectious Diseases, 31(9), 2105-2110.

24. Feldmeier H. 2014. Treatment of pediculosis capitis: a critical appraisal of the current literature. American Journal of Clinical Dermatology, 15(5), 401-412.

25. Firooziyan S, Sadaghianifar A, Taghilou B, Galavani H, Ghaffari E, Gholizadeh S. 2017. Identification of novel voltage-gated sodium channel mutations in human head and body lice (Phthiraptera: Pediculidae). Journal of Medical Entomology, 54(5), 1337-1343.

26. Fox K, Larkin K, Sanchez A. 2020. Global trends in genetic markers of Pediculus humanus capitis resistance mechanisms. Current Tropical Medicine Reports, 7, 65-73.

27. Gallardo A, Mougabure-Cueto G, Vassena C, Picollo MI, Toloza AC. 2012. Comparative efficacy of new commercial pediculicides against adults and eggs of Pediculus humanus capitis (head lice). Parasitology Research, 110(5), 1601-1606.

28. Gao J-R, Yoon KS, Lee SH, Takano-Lee M, Edman JD, Meinking TL, Taplin D, Clark JM. 2003. Increased frequency of the T929I and L932F mutations associated with knockdown resistance in permethrin-resistant populations of the human head louse, Pediculus capitis, from California, Florida, and Texas. Pesticide Biochemistry and Physiology, 77(3), 115-124.

29. Gellatly KJ, Krim S, Palenchar DJ, Shepherd K, Yoon KS, Rhodes CJ, Lee SH, Marshall Clark J. 2016. Expansion of the knockdown resistance frequency map for human head lice (Phthiraptera: Pediculidae) in the United States using quantitative sequencing. Journal of Medical Entomology, 53(3), 653-659.

30. Ghahvechi Khaligh F, Djadid ND, Farmani M, Asadi Saatlou Z, Frooziyan S, Abedi Astaneh F, Farnoosh F, Sofizadeh A, Naseri F, Adib D, Taheri M, Lalehzari E, Pashaei S, Soltanbeiglou S, Soltani A, Khooban H, Abbasi E, Aivazi AA, Saeedi S, Taghilou B, Jafari A, Khavidak KD, Toloza AC, Gholizadeh S. 2021. Molecular monitoring of knockdown resistance in head louse (Phthiraptera: Pediculidae) populations in Iran. Journal of Medical Entomology, 58(6), 2321-2329.

31. Goates BM, Atkin JS, Wilding KG, Birch KG, Cottam MR, Bush SE, Clayton DH. 2006. An effective nonchemical treatment for head lice: a lot of hot air. Pediatrics, 118(5), 1962-1970.

32. Hatam-Nahavandi K, Ahmadpour E, Pashazadeh F, Dezhkam A, Zarean M, Rafiei-Sefiddashti R, Salimi-Khorashad A, Hosseini-Teshnizi S, Hazratian T, Otranto D. 2020. Pediculosis capitis among school-age students worldwide as an emerging public health concern: a systematic review and meta-analysis of past five decades. Parasitology Research, 119, 3125-3143.

33. Hodgdon HE, Yoon KS, Previte DJ, Kim HJ, Aboelghar GE, Lee SH, Clark JM. 2010. Determination of knockdown resistance allele frequencies in global human head louse populations using the serial invasive signal amplification reaction. Pest Management Science, 66(9), 1031-1040.

34. Hunter J, Barker S. 2003. Susceptibility of head lice (Pediculus humanus capitis) to pediculicides in Australia. Parasitology Research, 90(6), 476-478.

35. Ismail MT, Kabakibi MM, Al-Kafri A. 2018. Epidemiology of pediculosis capitis among schoolchildren in Damascus, Syria. Indian Journal of Paediatric Dermatology, 19(4), 331.

36. Kalari H, Soltani A, Azizi K, Faramarzi H, Moemenbellah-Fard MD. 2019. Comparative efficacy of three pediculicides to treat head lice infestation in primary school girls: a randomised controlled assessor blind trial in rural Iran. BMC Dermatology, 19(1), 1-9.

37. Karakuş M, Atıcı T, Karabela ŞN, Baylan O, Limoncu ME, Balcıoğlu İC. 2020. Detection of permethrin resistance and phylogenetic clustering of turkish head lice (Pediculus humanus capitis; De Geer, 1767 populations. Acta Tropica, 204, 105362.
38. Kasai S, Ishii N, Natsuaki M, Fukutomi H, Komagata O, Kobayashi M, Tomita T. 2009. Prevalence of kdr-like mutations associated with pyrethroid resistance in human head louse populations in Japan. Journal of Medical Entomology, 46(1), $77-82$.

39. Kim HJ, Symington SB, Lee SH, Clark JM. 2004. Serial invasive signal amplification reaction for genotyping permethrin-resistant (kdr-like) human head lice, Pediculus capitis. Pesticide Biochemistry and Physiology, 80(3), 173-182.

40. Kristensen M, Knorr M, Rasmussen A-M, Jespersen JB. 2006. Survey of permethrin and malathion resistance in human head lice populations from Denmark. Journal of Medical Entomology, 43(3), 533-538.

41. Larkin K, Rodriguez CA, Jamani S, Fronza G, RocaAcevedo G, Sanchez A, Toloza AC. 2020. First evidence of the mutations associated with pyrethroid resistance in head lice (Phthiraptera: Pediculidae) from Honduras. Parasites \& Vectors, $13,312$.

42. Lee SH, Clark JM, Ahn YJ, Lee W-J, Yoon KS, Kwon DH, Seong KM. 2010. Molecular mechanisms and monitoring of permethrin resistance in human head lice. Pesticide Biochemistry and Physiology, 97(2), 109-114.

43. Lee SH, Yoon K-S, Williamson MS, Goodson SJ, Takano-Lee M, Edman JD, Devonshire AL, Clark JM. 2000. Molecular analysis of kdr-like resistance in permethrin-resistant strains of head lice, Pediculus capitis. Pesticide Biochemistry and Physiology, 66(2), 130-143.

44. Liao C-W, Cheng P-C, Chuang T-W, Chiu K-C, Chiang I-C, Kuo J-H, Tu Y-H, Fan Y-M, Jiang H-T, Fan C-K. 2019. Prevalence of Pediculus capitis in schoolchildren in Battambang, Cambodia. Journal of Microbiology, Immunology and Infection, 52(4), 585-591.

45. Liberati A, Altman DG, Tetzlaff J, Mulrow C, Gotzsche PC, Ioannidis JP, Clarke M, Devereaux PJ, Kleijnen J, Moher D. 2009. The PRISMA statement for reporting systematic reviews and meta-analyses of studies that evaluate health care interventions: explanation and elaboration. PLoS Medicine, 6(7), e1000100.

46. Lindh J, Mumcuoglu KY. 2012. Molecular analysis of pyrethroid resistance in Pediculus humanus capitis from Israel. Trends in Entomology, 8, 37-41.

47. Marcoux D, Palma KG, Kaul N, Hodgdon H, Van Geest A, Previte DJ, Abou-Elghar GE, Yoon KS, Clark JM. 2010. Pyrethroid pediculicide resistance of head lice in Canada evaluated by serial invasive signal amplification reaction. Journal of Cutaneous Medicine and Surgery, 14(3), 115-118.

48. Meinking TL, Vicaria M, Eyerdam DH, Villar ME, Reyna S, Suarez G. 2007. A Randomized, Investigator-blinded, timeranging study of the comparative efficacy of $0.5 \%$ malathion gel versus Ovide ${ }^{\circledR}$ lotion (0.5\% Malathion) or Nix ${ }^{\circledR}$ Crème Rinse (1\% Permethrin) used as labeled, for the treatment of head lice. Pediatric Dermatology, 24(4), 405-411.

49. Meinking TL, Villar ME, Vicaria M, Eyerdam DH, Paquet D, Mertz-Rivera K, Rivera HF, Hiriart J, Reyna S. 2010. The clinical trials supporting benzyl alcohol lotion 5\%(Ulesfiatm): a safe and effective topical treatment for head lice (Pediculosis humanus capitis). Pediatric Dermatology, 27(1), 19-24.

50. Moemenbellah-Fard M, Nasiri Z, Azizi K, Fakoorziba M. 2016. Head lice treatment with two interventions: pediculosis capitis profile in female schoolchildren of a rural setting in the south of Iran. Annals of Tropical Medicine and Public Health, 9(4), 245250.

51. Moemenbellah-Fard MD, Abdollahi A, Ghanbariasad A, Osanloo M. 2020. Antibacterial and leishmanicidal activities of Syzygium aromaticum essential oil versus its major ingredient, eugenol. Flavour and Fragrance Journal, 35(5), 534-540. 
52. Moosazadeh M, Afshari M, Keianian H, Nezammahalleh A, Enayati AA. 2015. Prevalence of head lice infestation and its associated factors among primary school students in Iran: a systematic review and meta-analysis. Osong Public Health and Research Perspectives, 6(6), 346-356.

53. Mumcuoglu KY, Pollack RJ, Reed DL, Barker SC, Gordon S, Toloza AC, Picollo MI, Taylan-Ozkan A, Chosidow O, Habedank B. 2021. International recommendations for an effective control of head louse infestations. International Journal of Dermatology, 60(3), 272-280.

54. Nejati J, Keyhani A, Kareshk AT, Mahmoudvand H, Saghafipour A, Khoraminasab M, Oliaee RT, Mousavi SM. 2018. Prevalence and risk factors of pediculosis in primary school children in South West of Iran. Iranian Journal of Public Health, 47(12), 1923.

55. Pearlman DL. 2004. A simple treatment for head lice: dry-on, suffocation-based pediculicide. Pediatrics, 114(3), e275-e279.

56. Pollack RJ, Kiszewski AE, Spielman A. 2000. Overdiagnosis and consequent mismanagement of head louse infestations in North America. Pediatric Infectious Disease Journal, 19(8), 689-694.

57. Ponce-Garcia G, Villanueva-Segura K, Trujillo-Rodriguez G, Rodriguez-Sanchez IP, Lopez-Monroy B, Flores AE. 2017. First detection of the Kdr mutation T929I in head lice (Phthiraptera: Pediculidae) in schoolchildren of the Metropolitan Area of Nuevo Leon and Yucatan, Mexico. Journal of Medical Entomology, 54(4), 1025-1030.

58. Rinkevich FD, Hedtke SM, Leichter CA, Harris SA, Su C, Brady SG, Taskin V, Qiu X, Scott JG. 2012. Multiple origins of kdr-type resistance in the house fly, Musca domestica. PloS One, 7(12), e52761.

59. Roca-Acevedo G, del Solar Kupfer CP, Dressel Roa P, Toloza AC. 2019. First determination of pyrethroid knockdown resistance alleles in human head lice (Phthiraptera: Pediculidae) from Chile. Journal of Medical Entomology, 56(6), 1698-1703.

60. Tagka A, Lambrou GI, Braoudaki M, Panagiotopoulos T, Papanikolaou E, Laggas D. 2016. Socioeconomical factors associated with pediculosis (Phthiraptera: Pediculidae) in Athens, Greece. Journal of Medical Entomology, 53(4), 919-922.

61. Thomas DR, McCarroll L, Roberts R, Karunaratne P, Roberts C, Casey D, Morgan S, Touhig K, Morgan J, Collins F. 2006. Surveillance of insecticide resistance in head lice using biochemical and molecular methods. Archives of Disease in Childhood, 91(9), 777-778.
62. Toloza AC, Ascunce MS, Reed D, Picollo MI. 2014. Geographical distribution of pyrethroid resistance allele frequency in head lice (Phthiraptera: Pediculidae) from Argentina. Journal of Medical Entomology, 51(1), 139-144.

63. Toloza AC, Lucía A, Zerba E, Masuh H, Picollo MI. 2010. Eucalyptus essential oil toxicity against permethrin-resistant Pediculus humanus capitis (Phthiraptera: Pediculidae). Parasitology Research, 106(2), 409-414.

64. Tytuła A, Bartosik K, Jasztal-Kniażuk A, Buczek W, Błaszkiewicz A, Borzecka-Sapko A. 2019. Analysis of the prevalence of pediculosis and scabies in orphanages and refugee shelters in south-eastern Poland. Journal of Education, Health and Sport, 9(3), 493-500.

65. Veracx A, Boutellis A, Raoult D. 2013. Genetic recombination events between sympatric Clade A and Clade C lice in Africa. Journal of Medical Entomology, 50(5), 1165-1168.

66. Veracx A, Raoult D. 2012. Biology and genetics of human head and body lice. Trends in Parasitology, 28(12), 563-571.

67. Verma P, Namdeo C. 2015. Treatment of pediculosis capitis. Indian Journal of Dermatology, 60(3), 238.

68. Von Elm E, Altman DG, Egger M, Pocock SJ, Gøtzsche PC, Vandenbroucke JP, Initiative S. 2014. The Strengthening the Reporting of Observational Studies in Epidemiology (STROBE) statement: guidelines for reporting observational studies. International Journal of Surgery, 12(12), 1495-1499.

69. Williamson MS, Denholm I, Bell CA, Devonshire AL. 1993. Knockdown resistance (kd r) to DDT and pyrethroid insecticides maps to a sodium channel gene locus in the housefly (Musca domestica). Molecular and General Genetics, 240(1), 17-22.

70. Yoon KS, Gao J-R, Lee SH, Clark JM, Brown L, Taplin D. 2003. Permethrin-resistant human head lice, Pediculus capitis, and their treatment. Archives of Dermatology, 139(8), 994-1000.

71. Yoon KS, Gao J-R, Lee SH, Coles GC, Meinking TL, Taplin D, Edman JD, Takano-Lee M, Clark JM. 2004. Resistance and cross-resistance to insecticides in human head lice from Florida and California. Pesticide Biochemistry and Physiology, 80(3), 192-201.

72. Yoon KS, Previte DJ, Hodgdon HE, Poole BC, Ho Kwon D, Abo El-Ghar GE, Lee SH, Clark JM. 2014. Knockdown resistance allele frequencies in North American head louse (Anoplura: Pediculidae) populations. Journal of Medical Entomology, 51(2), 450-457.

Cite this article as: Mohammadi J, Azizi K, Alipour H, Kalantari M, Bagheri M, Shahriari-Namadi M, Ebrahimi S \& MoemenbellahFard MD. 2021. Frequency of pyrethroid resistance in human head louse treatment: systematic review and meta-analysis. Parasite 28, 86.

Reviews, articles and short notes may be submitted. Fields include, but are not limited to: general, medical and veterinary parasitology; morphology, including ultrastructure; parasite systematics, including entomology, acarology, helminthology and protistology, and molecular analyses; molecular biology and biochemistry; immunology of parasitic diseases; host-parasite relationships; ecology and life history of parasites; epidemiology; therapeutics; new diagnostic tools.

All papers in Parasite are published in English. Manuscripts should have a broad interest and must not have been published or submitted elsewhere. No limit is imposed on the length of manuscripts.

Parasite (open-access) continues Parasite (print and online editions, 1994-2012) and Annales de Parasitologie Humaine et Comparée (1923-1993) and is the official journal of the Société Française de Parasitologie. 